\title{
An Assessment of Factors Affecting Implementation of Procurement Plans at County Government of Nakuru, Kenya
}

\author{
Jane Nderitu $^{1}$, Peter Mwaura ${ }^{2}$ \\ ${ }^{I}$ Student of MSc Procurement at Jomo Kenyatta University of Agriculture and Technology, Kenya \\ ${ }^{2}$ Senior Lecturer at Jomo Kenyatta University of Agriculture and Technology, Kenya
}

\begin{abstract}
Procurement plays a significant role in ensuring effective functioning and service delivery. The County Government of Nakuru has developed procurement plans. However, this has guarantee the implementation of the same. Kenyan public has lost money through failure to implement procurement plans. For example Shs. 1.6 billion was lost in the NYS scandal. It has been found that many County Governments fail to implement their procurement plans appropriately hence the said losses. The study investigated the influence of procurement staff capabilities and information technology infrastructure, on implementation of procurement plan at the County Government of Nakuru, Kenya. The target population of the study included all procurement staff in the ten ministries of the county. Due to a small number of the targeted respondents, the researcher used census technique to collect data from the respondents. This meant that the sample size of 40 was equal to the target population. Primary data was collected using questionnaires with both open and closed ended questions. Once the raw data was collected, the questionnaires were checked for proper recording of the responses and completeness. The information collected was coded and then analysed using Statistical Package for Social Sciences (SPSS) version 24.0. Results of the data analysis revealed that procurement staff capabilities $(\beta=0.351)$ and IT infrastructure $(\beta=0.198)$ in this order influenced implementation of procurement plans at the County Government of Nakuru.
\end{abstract}

\section{Introduction}

Procurement planning is the process that captures information on market demand and inventories, and combines it with supply capabilities and constraints to develop a plan for future volumes. It considers the complete supply chain, from raw material procurement to the distribution of finished products to customers, and targets increasing customer value and improving supply chain performance and cost efficiency. However, many organizations face numerous challenges in Procurement planning (Kumar, 2014).

The lack of integrated planning processes is a serious shortcoming, because it leads to many supply chain inefficiencies. Typically, these include high safety stocks, difficulties in managing seasonal demand patterns, insufficient demand forecasting, long planning horizons, and the inability to capture supply constraints concerning capacity or materials availability (Kumar, 2014)

Most developing countries are facing a problem of rapid changes in public procurement requirements. The changes are impacting pressure on how the procurement function performs its internal and external processes and procedures in order to achieve its objectives. The Kenyan Auditor General gave a report in 2016 indicating that implementation of procurement plans in most County Governments stood at less than $70 \%$ as at the end of 2015. The situation was severe in marginalized Counties where rate of implementation was as low as $45 \%$. Having ineffective procurement plan results in loss of value for money, therefore, the Kenyan government decided to put more effort to professional bodies to support and train people on procurement matters in order to obtain value for money procurement. Also the establishment of PPOA revealed more efforts on procurement matters by conducting different seminars/workshops and journals so as to bring awareness on procurement plan process in order to achieve the intended objectives.

The counties of Kenya are geographical units envisioned by the 2010 Constitution of Kenya as the units of devolved government. Following the re-organization of Kenya's national administration, counties were integrated into a new national administration with the national government posting county commissioners to represent it at the counties, (Constitution of Kenya 2010). Every county therefore has a mandate to plan for their procurement activities.

\section{Problem Statement}

Public procurement accounts for a sizeable proportion of the GDP. Procurement planning is one of the primary functions of procurement with a potential to contribute to the success of any business organization. It is a function that sets in motion the entire acquisition/procurement process of any business organization. Despite this importance and the numerous challenges like corruption, conflict of interest, Lack of Internal Engagement, IT challenges, and many other challenges in procurement activities, there is a very limited scientific research 
that has been done to examine the challenges facing county governments in Kenya in the implementation of procurement plans, (Kirungu, 2012). In Kenya Public procurement by central government is estimated to account for $10 \%$ of the GDP besides that of the County Governments (Juma, 2010). In the past Kenyan public have lost money by procuring entities failure to implement procurement plans effectively. For example Shs. 1.6 billion was lost in the NYS scandal. More money was lost through the IEBC 'chicken scandal'. However previous studies have not been able to pin point the kind of relationship and the specific areas of cooperation for effective execution of procurement plans. So far, few studies have been done in Nakuru County Government on procurement planning. This study therefore sought to make an assessment of the factors affecting implementation of procurement plans at Nakuru County Government, Kenya

\section{Study Objectives}

i. To establish how procurement staff capabilities influence the implementation of procurement plans at County Government of Nakuru.

ii. To assess if IT infrastructure influence implementation of procurement plans at County Government of Nakuru.

\section{Research Hypotheses}

H0 $_{1}$ : There is no significant difference between procurement staff capabilities and implementation of procurement plans at County Government of Nakuru.

$\mathbf{H O}_{2}$ : There is no significant difference between IT infrastructure and implementation of procurement plans at County Government of Nakuru.

\section{Literature Review}

While there have been developments in regulatory framework, there is still challenges to be addressed in order to realize full benefits of procurement planning in Kenya. Some of the notable challenges include; regulatory gap in procurement planning in County Governments (Owalla, 2012), institutional and professional capacity challenges (PPOA, 2007), political interference with implementation of regulations (CCG, 2007) and the low level of implementation of Information Communication (ICT) tools Kenya Institute for Public Policy Research and Analysis (KIPPRA, 2010). Most of the literature shows that, there is abuse of the procurement rules and regulations, but very little is said on the role of procurement planning which seems to be the missing tie in the progressive regulations that have been developed. While the existing studies (CCG, 2007) focus on the identification of gaps in procurement planning.

Although procedures supporting systematic procurement planning have been established, data from CPI survey (2007) indicates that these are far from always being complied with. While it has not been possible to assess the percentage of contracts which are not part of procurement plans, the low share of procurements conducted through open tendering indicates that a large part of procurements are undertaken on an ad hoc basis, by quotations and direct procurements, thus suggesting a lack of procurement planning in the County.

Whereas previous studies have always looked at procurement planning and its effect on organizational performance not all factors have been dealt with within the county governments. The aim of the Public Procurement Regulations of 2006 was to promote fairness, accountability and procedures in procurement in public institutions with the main aim of ensuring efficient use of public funds. However, studies reveal that even after the enactment of the Regulations there are losses of public funds that can be attributed to public procurement. Further, studies indicate dissatisfaction among stakeholders brought about by loopholes left by the Regulations which may be used by dishonest people to make the process inefficient.

\section{Research Design}

\section{Methodology}

This study adopted a descriptive research design. This research design enabled the researcher to keep track of the research activities and helped to ensure that the ultimate research objectives were achieved.

\section{Study Population}

The target population consisted of employees in procurement department in the ten ministries at the County government of Nakuru. The ministries were: Finance and economic planning; Agriculture and livestock; Environment and national resources; Health and services; Education culture, social; Physical planning/housing; Public works and utilities; Public service management; Trade and industrial development, and; Roads and transport. The target population consisted of 40 respondents selected from the 10 ministries. Due to a small number of the targeted respondents, the researcher used census technique to collect data from the respondents. This meant that the sample size was 


\section{Research Instruments}

Primary data was collected using questionnaires with both open and closed ended questionnaires. Penended questions are important because they permit a greater depth of response to questions that need more explanation. The closed ended questions were used because they provided alternatives of answers from which respondents selected the answer because they were easier to analyze and are economical in terms of time.

\section{Data Analysis and Presentation}

Once the raw data was collected, the questionnaires were checked for proper recording of the responses and completeness. The information collected was coded and was then analyzed using Statistical Package for Social Sciences (SPSS) version 24.0.

\section{Influence of Procurement Staff Capabilities}

\section{Findings}

The study sought to establish how procurement staff capabilities influence the implementation of procurement plans at County Government of Nakuru. To address this, a number of possible reasons were put forward by the researcher of which respondents were to rate them on the basis of their level of agreement. The responses of this variable were rated on a 5 point Likert scale ranging from; $1=$ strongly agree to $5=$ strongly disagree. Table 1 shows the opinion rating related to procurement staff capabilities.

Table 1: Influence of Procurement Staff Capabilities

\begin{tabular}{|c|c|c|c|c|c|}
\hline & $\mathbf{N}$ & Min & Max & Mean & Std. Deviation \\
\hline Qualified staff gives higher turnover in terms of production. & 34 & 3 & 5 & 4.41 & 0.609 \\
\hline $\begin{array}{l}\text { Qualified staff has greater initiative to perform well since professionalism is } \\
\text { valued. }\end{array}$ & 34 & 4 & 5 & 4.53 & 0.507 \\
\hline $\begin{array}{l}\text { Very expensive for the employer as they have to pay more for services of } \\
\text { qualified staff. }\end{array}$ & 34 & 3 & 5 & 4 & 0.696 \\
\hline Highly experienced personnel generates a proficient workforce & 34 & 2 & 5 & 3.97 & 0.797 \\
\hline $\begin{array}{l}\text { Considering that they are highly qualified they operate as expert and also } \\
\text { with a great result on the respective responsibilities. }\end{array}$ & 34 & 2 & 5 & 4.06 & 0.736 \\
\hline $\begin{array}{l}\text { It is effortless to experienced staff to learn the new things, guidelines and } \\
\text { also regulation, perform their relevant tasks as well with much ease. }\end{array}$ & 34 & 1 & 5 & 3.5 & 1.052 \\
\hline
\end{tabular}

From the findings majority of the respondents strongly agreed that qualified staff gives higher turnover in terms of production. This was shown by a mean score of 4.41.Respondents also strongly agreed that qualified staff has greater initiative to perform well since professionalism is valued as shown by a mean score of 4.53. It was also revealed that it was easy for qualified procurement staff to deal with for manager as he or she can delegate work better. This was shown by a mean score of 3.97. Further findings showed that it was very expensive for the employer as they have to pay more for services of qualified staff as depicted by a mean of 4 . Highly experienced personnel generate a proficient workforce as shown by a mean score of 3.97. Consequently respondents agreed that experienced staff put the organization in a much better position as well as gives a competitive advantage earlier than the competition as shown by a mean score of 3.97. Similarly the respondents strongly agreed that considering that they are highly qualified they operate as expert and also with a great result on the respective responsibilities. This was indicated by a mean score of 4.06. It was also revealed that it is effortless to experienced staff to learn the new things, guidelines and also regulation, perform their relevant tasks as well with much ease (mean $=3.5)$

In general, all the statements had a mean of above 3.5 meaning that the respondents agreed to all the statements relating to procurement staff capabilities. Therefore, the results implied that qualified and experienced employees will positively influence implementation of procurement plans at County governments.

\section{Influence of Information Technology Infrastructure}

The second objective sought to assess if IT infrastructure influence implementation of procurement plans at County Government of Nakuru. Procurement staffs were required to agree or disagree with statements of fact put forward to them regarding the effect of IT infrastructure and implementation of procurement planning. A descriptive analysis of the findings in view of this objective is presented in Table 2 
Table 2: Influence of Information Technology Infrastructure

\begin{tabular}{|l|l|l|l|l|l|}
\hline & $\mathbf{N}$ & $\mathbf{M i n}$ & $\mathbf{M a x}$ & Mean & Std. Deviation \\
\hline $\begin{array}{l}\text { The organization IT infrastructure is not in line with the implementation } \\
\text { of procurement plans. }\end{array}$ & 34 & 1 & 5 & 3.32 & 1.249 \\
\hline All procurement records are digitalized for easy reference & 34 & 2 & 5 & 3.65 & 1.07 \\
\hline $\begin{array}{l}\text { Use of ICT in our procurement function has led to considerable savings } \\
\text { in terms of time and money }\end{array}$ & 34 & 2 & 5 & 3.85 & 1.048 \\
\hline $\begin{array}{l}\text { The procurement portal in the institution's website has been } \\
\text { instrumental in getting the bidders and managing their applications and } \\
\text { this has greatly aided the procurement unit performance }\end{array}$ & 34 & 3 & 5 & 4.12 & 0.591 \\
\hline $\begin{array}{l}\text { Technology adoption has considerably improved our procurement unit } \\
\text { performance in the last five years }\end{array}$ & 34 & 3 & 5 & 3.91 & 0.621 \\
\hline
\end{tabular}

The respondents strongly agreed that the organization IT infrastructure is not in line with the implementation of procurement plans as indicated by a mean of 3.32. However the respondents agreed that all procurement records are digitalized for easy reference as shown by a mean of 3.65.The respondents also agreed that the use of ICT in our procurement function has led to considerable savings in terms of time and money as revealed by a mean of 3.85.The respondents strongly agreed to with mean of 4.12 that the procurement portal in the institution's website has been instrumental in getting the bidders and managing their applications and this has greatly aided the procurement unit performance. Respondents held the opinion (mean 3.91) that technology adoption has considerably improved procurement unit performance in the last five years.

Without distinction of one indicator from others, procurement staff at the County Government of Nakuru agreed to all the statements concerning the influence of Information Technology. These findings implied that technology adoption has considerably improved procurement unit performance at the county government of Nakuru and thus proper implementation of procurement plans.

\section{Hypotheses Testing}

The first hypothesis of the study stated " $\mathrm{H}_{01}$ : There is no significant difference between procurement staff capabilities and implementation of procurement plans at County Government of Nakuru. The decision rule in the test is that when $\mathrm{P}$ value $<0.05$ there is statistical significance and when $\mathrm{P}$ value $>0.05$, there is no statistical significance. The null hypothesis should be accepted if $\mathrm{P}<0.05$ and rejected if $\mathrm{P}>0.05$. From the findings in table $4.11, \mathrm{t}=2.562$ imply that procurement staff capabilities has influence on implementation of procurement plans. Similarly, $\mathrm{p}=.011(<0.05)$ indicate that the effect is statistically significant. The first null hypothesis was therefore rejected and alternative hypothesis accepted. It was concluded that there is significant difference between procurement staff capabilities and implementation of procurement plans at County Government of Nakuru.

The second hypothesis was stated that " $\mathrm{H}_{02}$ : There is no significant difference between IT infrastructure and implementation of procurement plans at County Government of Nakuru.' The decision rule in the test is that when $\mathrm{P}$ value $<0.05$ there is statistical significance and when $\mathrm{P}$ value $>0.05$, there is no statistical significance. The null hypothesis should be accepted if $\mathrm{P}<0.05$ and rejected if $\mathrm{P}>0.05$. From table 4.11, $\mathrm{t}=1.242$ implies that IT infrastructure has influence on implementation of procurement plans. Consequently, $\mathrm{p}=.015(<0.05)$ implies that the effect is statistically significant. The second null hypothesis was therefore rejected and alternative hypothesis accepted. It was concluded that there is a significant difference between IT infrastructure and implementation of procurement plans at County Government of Nakuru.

\section{Conclusions}

The study concludes that budgetary allocation is the most important factor that affects implementation of procurement plans at the County Government of Nakuru. The optimal model of the study shows that budgetary allocation has a significant influence of 0.398 on implementation of procurement plans. This implies that increasing levels of budgetary allocation by a unit would increase the levels of implementation of procurement plans by 0.398 . This shows that budgetary allocation has a positive influence on implementation of procurement plans.

Procurement staff capability is the second important factor that influenced implementation of procurement plans at the County Government of Nakuru. The optimal model of the study shows that increasing levels of procurement staff capabilities by a unit would increase the levels of implementation of procurement plans by 0.351 . According to the study findings, procurement staff capabilities factors such as qualifications, experience and leadership style to a large extent influenced implementation of procurement plans at the County Government of Nakuru. 


\section{References}

[1]. CCG (2007). National Development Fund Report Instructional Structures and Reforms. Nairobi: Centre for Corporate Governance. Retrieved April 2007

[2]. Juma, M. J. (2010). Procurement Reforms. Kenya Procurement Journal, No. 5.72-95.

[3]. Kirungu, 2012).Factors Affecting Purchasing Budgetary Allocation in Cooperative Societies. Makerere University.

[4]. Kumar, S. and Maher, M. (2014), "Are the temptations of online reverse auctions appropriate for your business?" Supply Chain Management: An International Journal, Vol. 13, pp. 304-16.

[5]. Owalla, C. (2012). A Report on Management of Devolved Funds: A case Study of Kisumu Municipality. A Network of Civil Society Organization-Ufadhili Trust.

[6]. PPOA. (2007). Assessing Procurement Systems in Kenya Report. Nairobi: Public Oversight Authority. 